\title{
Enhancing Reliability of Photovoltaic (PV) System By Using Energy Storage
}

\author{
Daifallah Dalabeih", Mohammad Hussein, Batool Aldardisi, Israa Huwarat and Mohammad Abu omar \\ Electrical Engineering Department Faculty of Engineering, University Of Jordan, Amman 11942 - Jordan \\ ${ }^{*}$ Corresponding author
}

\begin{abstract}
This paper presents a study of increasing the reliability of a small $1 \mathrm{~kW}$ installed photovoltaic system by using hydrogen storage technique.
\end{abstract}

Keywords-reliability; photovoltaic; renewable energy; energy storage

\section{INTRODUCTION}

Renewable energy sources, such as PV systems, became of international interest in order to decrease the dependence on conventional methods of generating electrical energy and to have clean environmental energy sources. This is also accelerated due to rapid decrease in the cost of such systems. The objective of the paper is to find the amount of improvement in the reliability of a small $1 \mathrm{~kW}$ PV system installed at the faculty of engineering of the university of Jordan. Mathematical analysis was performed on a simulation using hydrogen storage and fuel cells.

\section{PV SySTEM With HydROGEN STORAGE}

Figure 1 shows $1 \mathrm{~kW}$ PV system that through a controller has two possible paths:

A. on-load: during the working hours a $1 \mathrm{kw}$ load is supplied through an inverter.

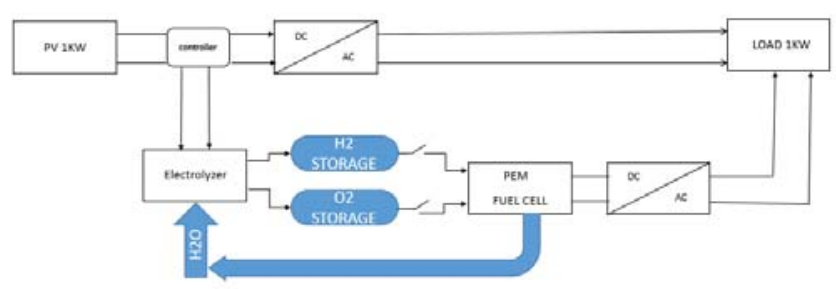

FIGURE I. BLOCK DIAGRAM OF THE PV SYSTEM

B. off-load: outside the working hours the output of the PV is supplied to an electrolyzer to generate hydrogen and oxygen. The hydrogen is stored in order to be used later by fuel cell to generate electrical energy and become another source for the load. This storage concept was used to improve the reliability of the PV system.

\section{ANNUAL TIME FOR ENERGy STORAGE}

This annual time was calculated as follows:
A. The sunrise time, sunset time and number of sunny hours per day were recorded and calculated for each month of the year. For e.g. in the month of June those were 05.30, 19.44 and 14.14 respectively.

B. By assuming the number of working hours per day is 7 , then the number of hours per day which can be used for energy storage in June is (14.14 -7=7.14).

C. By assuming that the number of working days per month is 22 and the number of weekend days per month is 8 , then the total number of hours in June which can be used for energy storage is $(7.14 * 22)+(19.44-05.30) * 8=270.20$ hours.

D. By repeating the same procedure for each month, it was found that the total annual time which can be used for energy storage is 2827.1 hours.

\section{HYDROGEN PRODUCTION}

The amount of hydrogen which the electrolyzer can produce during the 2827.1 hours can be calculated by using the following equations [1]:

number of cells required $\left(\mathrm{n}_{\mathrm{c}}\right)=$ input voltage/voltage per cell

input current, I=input power/input voltage

hydrogen production rate $=\mathrm{n}_{\mathrm{c}} * \mathrm{I} / \mathrm{n} * \mathrm{~F}$

$\mathrm{n}=$ number of moles of electrons per mole of water $=2$

$\mathrm{F}=$ Faraday's constant $=96485 \mathrm{C} \mathrm{mol}^{-1}$ data:

The above equations were applied by using the following

input power to electrolyzer $=1000 \mathrm{~W}$

input voltage $=16.8$

voltage of each cell $=1.388 \mathrm{~V}$

number of cells needed, $\mathrm{n}_{\mathrm{c}}=16.8 / 1.388=12$

input current, $\mathrm{I}=1000 / 16.8=59.5238 \mathrm{~A}$

the hydrogen production rate can be obtained by substituting into (3), which give $3.7015^{*} 10^{-3} \mathrm{~mol} / \mathrm{sec}=4.974849 \mathrm{liter} / \mathrm{min}$.

Hence the total annual amount of hydrogen production in the 2827.1 hours period is 843863.74 liter. This amount can be stored in containers to be used later on as input for the fuel cell which will generate electrical energy when it is required. 
The duration of this generation can be calculated as

follows by using the following data;

output power of fuel cells $=1000 \mathrm{~W}$

output voltage $=16.8 \mathrm{~V}$

voltage per cell $=0.77 \mathrm{~V}$

by using (3) it gives the rate of hydrogen consumption by the fuel cells of 9.120556 liter/min.

hence, the duration of power supplied by fuel cells=

available amount of hydrogen/rate of consumption=

1542.0546 hours.

\section{RELIABILITy ANALYSIS}

The objective of the paper was achieved by evaluating the Expected Energy Not Supplied (EENS) by the PV system without and with energy (hydrogen) storage. The carried procedure was as follows [2]:

\section{A. Generation Model}

In the first case (i.e. without storage) the only source for the load is the PV system which consists of $10^{*} 100 \mathrm{~W}$ panels. It was assumed that each panel has a forced outage rate of 0.02 . Since the panels are identical then by using the binomial distribution the capacity outage probability table was obtainedas shown in Table 1. Capacity outages greater than $500 \mathrm{~W}$ were ignored because their probability is negligible.

\section{TABLE I. CAPACITY OUTAGE TABLE}

$\begin{array}{cc}\text { Capacity outage } & \text { Probability } \\ 0 & 0.817073 \\ 100 & 0.166749 \\ 200 & 0.015314 \\ 300 & 0.000833 \\ 400 & 0.000029 \\ 500 & 0.000029\end{array}$

\section{B. Load Model}

The load was represented by a linear load duration curve for a total duration of 1542.0546 hours. It was assumed that the peak and minimum loads were 1000 and $400 \mathrm{~W}$ respectively. Here the installed capacity is equal to the peak load of $1000 \mathrm{~W}$.

\section{Risk Index without Storage}

The generation and load models were used to find for each capacity outage state the energy curtailed, expected energy curtailed and the total EENS as shown in table 2. It can be found that the risk in the case of PV without storage is 3032.4954 Wh.

\section{TABLE II. EENS BY PV WITHOUT ENERGY STORAGE}

\begin{tabular}{|c|c|c|c|}
\hline $\begin{array}{l}\text { Capacity } \\
\text { out (W) }\end{array}$ & Probability & $\begin{array}{c}\text { Energy } \\
\text { curtailed (Wh) }\end{array}$ & $\begin{array}{l}\text { Expected } \\
\text { (Wh) }\end{array}$ \\
\hline 0 & 0.817073 & 0.0 & 0.0 \\
\hline 100 & 0.166749 & 12850.4550 & 2142.8005 \\
\hline 200 & 0.015314 & 51401.8200 & 787.1675 \\
\hline 300 & 0.000833 & 115654.0950 & 96.3399 \\
\hline 400 & 0.000029 & 205607.2800 & 5.9626 \\
\hline 500 & 0.0000007 & 321261.3750 & 0.2249 \\
\hline
\end{tabular}

\section{Risk Index with Storage}

In this case the load has two sources, the PV and the fuel cells. Since the hydrogen electrolysis depends on the output of the PV and this output changes through the different seasons of the year, then the fuel cell output was represented as a multistate generating unit. These multi states are shown in Table 3.

\begin{tabular}{|c|c|c|}
\hline Capacity out (W) & Capacity in (W) & Probability \\
\hline 0 & 1000 & 0.36617 \\
\hline 76.1207 & 923.8793 & 0.338297 \\
\hline 192.9096 & 807.0904 & 0.295532 \\
\hline
\end{tabular}

Tables 1 and 3 were combined in order to find the overall capacity outage table of the system with energy storage. A sample of this is shown in Table 4.

TABLE IV. A SAMPLE FOR THE OVERALL SYSTEM

\begin{tabular}{|c|c|c|c|}
\hline $\begin{array}{l}\text { Capacity } \\
\text { out (W) }\end{array}$ & probability & $\begin{array}{c}\text { Energy } \\
\text { curtailed (Wh) }\end{array}$ & $\begin{array}{l}\text { Expected } \\
\text { (Wh) }\end{array}$ \\
\hline 0 & 0.299188 & 0 & 0 \\
\hline 76.1207 & 0.276413 & 0 & 0 \\
\hline 100 & 0.061058 & 0 & 0 \\
\hline 276.1207 & 0.005181 & 0 & 0 \\
\hline 400 & 0.000011 & 0 & 0 \\
\hline 692.9096 & 0.0000002 & 0 & 0 \\
\hline
\end{tabular}

The load model is the same as in the case without storage, but the installed capacity now is $2000 \mathrm{~W}$. Hence for any capacity outage there is not energy curtailed. Therefore, the risk index of EENS is zero.

\section{CONCLUSIONS}

The reliability index of EENS was used to see the effect of energy storage on the reliability of a small installed PV system. The o bjective was achieved by carrying out probabilistic mathematical analysis.

\section{REFERENCE}

[1] Ulleberg Ø. Stand-alone power systems for the future:optimal design, Operation \& control of solar-hydrogen energy systems [Ph.D.Thesis]. Trondheim, Norway: Department of Thermal Energy and Hydropower, Narwegian University of science and technology;1998.

[2] Roy Billinton, Ronald N Allan, "Reliability evaluation of Power systems,” Pitman Publishing Limited, London, 1984. 